\title{
Metal Oxide Nanoparticles in Therapeutic Regulation of Macrophage Functions
}

\author{
Marina S. Dukhinova ${ }^{1}$, Artur. Y. Prilepskii ${ }^{1}{ }^{\circledR}$, Alexander A. Shtil ${ }^{1,2}$ and \\ Vladimir V. Vinogradov ${ }^{1, *(D)}$ \\ 1 ITMO University, Saint-Petersburg 197101, Russia; marina_dukhinova@mail.ru (M.S.D.); \\ prilepskii@gmail.com (A.Y.P.); shtil@scamt-itmo.ru (A.A.S.) \\ 2 Blokhin National Medical Center of Oncology, Moscow 115478, Russia \\ * Correspondence: vinogradov@scamt-itmo.ru; Tel.: +7-921-890-6773
}

Received: 30 October 2019; Accepted: 13 November 2019; Published: 16 November 2019

\begin{abstract}
Macrophages are components of the innate immune system that control a plethora of biological processes. Macrophages can be activated towards pro-inflammatory (M1) or anti-inflammatory (M2) phenotypes depending on the cue; however, polarization may be altered in bacterial and viral infections, cancer, or autoimmune diseases. Metal (zinc, iron, titanium, copper, etc.) oxide nanoparticles are widely used in therapeutic applications as drugs, nanocarriers, and diagnostic tools. Macrophages can recognize and engulf nanoparticles, while the influence of macrophage-nanoparticle interaction on cell polarization remains unclear. In this review, we summarize the molecular mechanisms that drive macrophage activation phenotypes and functions upon interaction with nanoparticles in an inflammatory microenvironment. The manifold effects of metal oxide nanoparticles on macrophages depend on the type of metal and the route of synthesis. While largely considered as drug transporters, metal oxide nanoparticles nevertheless have an immunotherapeutic potential, as they can evoke pro- or anti-inflammatory effects on macrophages and become essential for macrophage profiling in cancer, wound healing, infections, and autoimmunity.
\end{abstract}

Keywords: nanoparticles; metal oxides; macrophages; inflammation; signal transduction; immunotherapy

\section{Introduction}

Macrophages (MФs) are the essential components of innate immunity. These active phagocytes are the first encounter for external substances, including nanoparticles (NPs). The so-called industrial NPs enter our organism in a non-specific way, as they can be delivered via inhalation, food or water intake, and skin exposure. The emerging medical applications of NPs, in particular, metal oxide NPs (MONPs), raise new questions regarding mechanisms, immunological aspects, and therapeutic relevance of $M \Phi-N P$ interaction in a wide variety of physiological and pathological situations. It is well known that $M \Phi$ s respond to various stimuli and obtain distinct functional profiles to shape the functions of innate and adaptive immune cells. However, the mechanisms and outcomes of M $\Phi-N P$ interaction remain unclear.

\section{Metal Oxide Nanoparticles: a General Overview}

\subsection{Synthesis of Metal Oxide Nanoparticles}

Presently, there are numerous synthetic procedures to obtain MONPs of almost any shape, size, and surface structure. There are three major types of MONP synthesis: physical (laser ablation, 
ultrasonication, spray pyrolysis, vaporization), chemical (sol-gel, hydrothermal, co-precipitation), and biological. The selected method determines the physicochemical characteristics of MONPs and the type of defects, morphology, and crystal structure [1]. Although the large-scale production of many kinds of MONPs is questionable and not a major contributor to environmental pollution, the bio-inspired, or green synthesis methods attract growing attention. These methods usually involve "wet" chemical synthesis in aqueous, ethanol, or other types of extracts obtained from plants, fungi, bacteria, or algae. Also, the major difference between the use of harsh/hazardous chemicals and extracts is that the obtained MONPs are generally functionalized by phytochemicals and are, therefore, biocompatible [2]. However, the yield and monodispersity of bio-prepared NPs, as well as reproducibility, are insufficient, due to differential concentrations of active compounds in raw material [3]. Also, mechanisms of "green" MONPs formation remain poorly investigated and deserve a more detailed analysis [4].

\subsection{Variability of Metal Oxide Nanoparticles}

Currently, MONPs of almost 30 different chemical elements are described [5]. Among the most common are alumina [6,7], cerium [8], cobalt [9], copper [10], iron [11,12], gadolinium [13], hafnium [14], magnesium [15], manganese [16], silica, titanium [17], and zinc [18] MONPs.

Cerium oxide has emerged as a "hot" topic in nanobiomedicine [19]. Cerium oxide NPs (nanoceria) have been showed to provide neuroprotective [20], antioxidant [21], antibacterial [22] effects. These materials can be synthesized by a variety of methods, including chemical fabrication via oxidation of cerium (III) ions by apoferritin [23], or green chemicals, such as leaf extracts of Gloriosa superba L. [24] or Acalypha indica [25].

Magnesium oxide NPs for antimicrobial and anticancer applications have been obtained by reduction from magnesium nitrate using bioactive compounds from algae Sophora wightii [26]. The aqueous extract of Aspalathus linearis, commonly known as rooibos, has been used to reduce palladium and nickel from palladium (II) chloride and nickel (II) nitrate hexahydrate to form PdO and $\mathrm{NiO} N \mathrm{NP}$ [27].

Zinc oxide NPs are widely used as antimicrobial agents [28,29]. Contrary to previously described synthetic procedures, general methods for ZnO NPs preparation are the mechanochemical processing and physical vapor synthesis. Mechano-assisted methods are conducted in a ball mill by mixing zinc chloride with sodium carbonate following by heat treatment [30]. In PVC methods, a solid precursor is evaporated by plasma arc and then cooled and condensed in a controlled manner to obtain NPs [31]. Titanium dioxide and zinc oxide NPs are common ingredients in many commercially available cosmetics, such as sunscreens. The way of formation of these NPs is unknown, but in individual studies, their properties have been addressed, which will help to estimate their possible toxicity [32].

Iron oxide NPs (mostly, magnetite) have been approved by FDA and EMA for drug delivery [33], hyperthermia [34], or as a stand-alone drug [35]. A plethora of methods, as well as application strategies, have been comprehensively described in a recent review on magnetite NPs [36].

Copper and cobalt are the microelements essential for plant growth [37]. Recently, copper and cobalt oxide NP powders have been synthesized $[38,39]$. However, the fate of these NPs and their impact on consumers remain to be investigated. In these studies, NPs were obtained by wire electric explosion in an inert atmosphere under low pressure, which results in a pure metal oxide shell on the surface of NPs. In general, the presence of NPs in the soil can be a major problem and may lead to their accumulation in food crops, livestock, and in humans [40].

\subsection{Stabilization of Metal Oxide Nanoparticles in a Biological Microenvironment}

Different polymers, polyelectrolytes, or proteins are often used to stabilize the prepared NPs. These modifications can seriously alter biodistribution and toxicity. Bovine or human serum albumins can be used to functionalize both the synthesized NPs [41] or during synthesis [42]. However, even these 
native proteins can provoke an undesired immune response due to protein misfolding upon their binding to the NP surface. Other commonly used stabilization agents, such as polyethyleneimine (PEI) and poly(lactide-co-glycolide) (PLGA), can also be responsible for M $\Phi$ activation [43]. Furthermore, surface coating with serum proteins (i.e., protein corona effect) is known to alter immunogenic properties and clearance of NPs [44]. Considering the fact that protein corona largely depends on size, surface charge, and shape of NPs, its chemical composition is not important [45].

Not only single-metal NPs but also polymetallic NPs like ZnMgO have been reported [1]. The latter materials showed a lesser tendency to aggregate in biological fluids and an increased antibacterial activity [1]. Complexes of MONPs with metal-organic frames have been described for gas storages and separators, catalysis platforms, sensors, and drug delivery platforms [46,47]. Thus, MONPs can be synthesized by a variety of methods. Regardless of this variability, MONPs enter the body through the lungs or with food, or as drugs and primarily interact with the immune system.

\section{Macrophage Polarization as an Essential Response for Altered Cell Microenvironment}

$\mathrm{M} \Phi$ s are a heterogeneous cell population of the myeloid lineage that exhibits phagocytic activity and participates in innate and adaptive immune reactions. $M \Phi$ populations include blood-circulating monocytes derived from the bone marrow in adult mammals and tissue-resident MФs that have exclusive routes of embryonic development and may also arise from mononuclear cells that populate

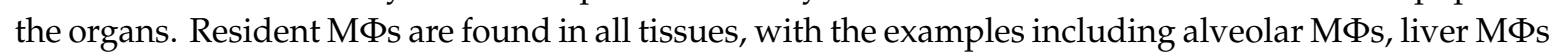
named Kupffer cells, brain resident microglia, etc. [48]. Major local or systemic changes in the organism, such as microbial or protozoan pathogens, trauma, or tumor growth, cause activation and infiltration of blood monocytes and polarization of tissue-resident MФs. Activated MФs are commonly divided into two subsets, that is, the classical (M1; pro-inflammatory) and alternative (M2; anti-inflammatory) (Figure 1).

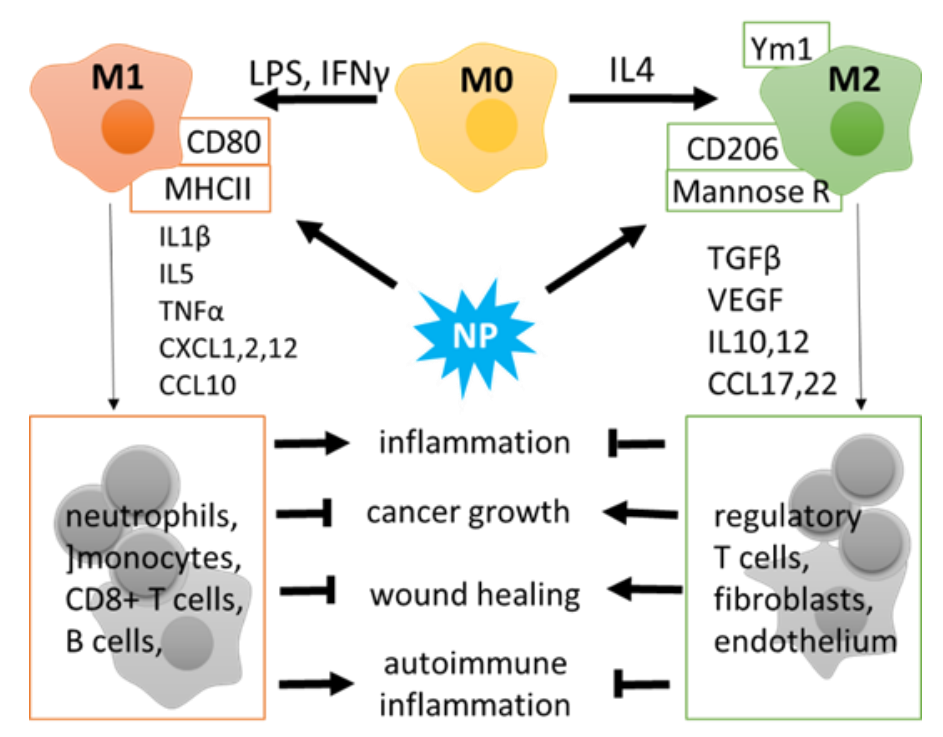

Figure 1. Macrophage polarization: M1 (classical, pro-inflammatory) and M2 (alternative, anti-inflammatory). M1 polarization can be triggered by lipopolysaccharides (LPS) and/or interferon gamma (INF $\gamma$ ). M1 macrophages express high CD80 and MHCII and produce pro-inflammatory cytokines to stimulate the innate and adaptive immune activity of monocytes, neutrophils, T- and B-lymphocytes. M2 cells are characterized by surface markers Ym1, CD206, and mannose receptor, as well as by cytokines that have a potential for immunosuppression and tissue regeneration. Tumor-associated macrophages develop an M2 phenotype and promote the immune escape of tumor cells. 
M1-like M $\Phi$ s are characterized by the ability to release pro-inflammatory (interleukin 1 beta, Il1 $\beta$, $\mathrm{TNF} \alpha$ ) and chemoattractant (CXCL3, -8, -10) cytokines and play an essential role in the elimination of pathogens, damaged or transformed cells, and recruitment of other immune cells to the pathological site [49,50]. However, M1 cells can also promote a cytotoxic effect in a prolonged inflammation: harming normal cells by mistake and attracting CD8+ T and B lymphocytes to attack the surrounding tissues in neurodegeneration or autoimmunity (Figure 1). M2-like MФs produce anti-inflammatory molecules and growth factors (Il10, TGF $\beta$, VEGF) to control immunity and promote regeneration. At the same time, M2 profiling correlates with a poor prognosis in cancer and infections [51]. The division into proand anti-inflammatory subsets reflects the major functional activity of MФs; however, in vivo some stimuli drive $\mathrm{M} \Phi$ polarization towards different directions; these routes can be modified by therapeutic interventions including exposure to NPs. (Figure 1).

Current immunotherapy takes advantage of several approaches for M $\Phi$ modulation, with NPs as an attractive tool. MONPs are of particular interest as they exhibit minor toxicity toward the immune cells and are able to reshape immunity both on local or systemic levels. The immunotherapeutic potential of these NPs for M $\Phi$ activities and the immune system, in general, is an emerging issue (Table 1) [10,52-54].

Table 1. Effects of MONPs on pro- and anti-inflammatory activities of MФs.

\begin{tabular}{|c|c|c|}
\hline Macrophage Cells/ & \multirow{2}{*}{ Functional Effect of Nanoparticles } & \multirow{2}{*}{ Reference } \\
\hline \multirow{2}{*}{\multicolumn{3}{|c|}{ In Vivo Model }} \\
\hline & & \\
\hline $\begin{array}{l}\text { Kupffer cells and peripheral } \\
\text { macrophages from LPS-treated mice }\end{array}$ & $\begin{array}{l}\text { Reduced NFKB TF activity, cytokine and ROS } \\
\text { release, reduced inflammation }\end{array}$ & Selvarai et al., 2015 [55] \\
\hline $\begin{array}{l}\text { RAW } 264.7 \text { following } \\
\text { oxidative stress }\end{array}$ & Reduced ROS release & Xia et al., 2008 [56] \\
\hline Rat model of liver fibrosis & Reduced M $\Phi$ activation and cytokine release & Oro et al., 2016 [8] \\
\hline \multicolumn{3}{|c|}{ Zinc oxide NPs } \\
\hline $\begin{array}{l}\text { RAW } 264.7 \text { stimulated with LPS } \\
\text { and IFN } \gamma\end{array}$ & $\begin{array}{l}\text { Reduce NFkB TF activity, Il1 } \beta \\
\text { and TNFa release }\end{array}$ & Kim \& Jeong, 2015 [57] \\
\hline $\begin{array}{l}\text { Blood mononuclear cells stimulated } \\
\text { with LPS }\end{array}$ & $\begin{array}{l}\text { Reduced II1 } \beta \text { and IL6 production. Activation of } \\
\text { eIF2, eIF4 and mTOR pathways }\end{array}$ & $\begin{array}{l}\text { Makumire et al., } \\
\quad 2014 \text { [58] }\end{array}$ \\
\hline Alveolar macrophages from infected & $\begin{array}{c}\text { Decreased NFkB activation and NO release, } \\
\text { suppressed bacterial clearance }\end{array}$ & Lin et al., 2014 [59] \\
\hline & $\begin{array}{l}\text { Reduced oxidative stress: aromatase expression, } \\
\text { glutathione peroxidase, and reductase activity }\end{array}$ & \\
\hline Burn wounds & $\begin{array}{l}\text { Improved anti-microbial activity and } \\
\text { wound healing; }\end{array}$ & Ali et al., 2017 [60] \\
\hline & $\begin{array}{l}\text { inhibited albumin denaturation and } \\
\text { proteinase activity }\end{array}$ & $\begin{array}{l}\text { Seisenbaeva et al., } \\
2017 \text { [61] }\end{array}$ \\
\hline Atopic dermatitis & $\begin{array}{l}\text { Decreased F4/80+ macrophage infiltration, } \\
\text { reduce pro-inflammatory cytokines }\end{array}$ & Ilves et al., 2014 [62] \\
\hline $\begin{array}{l}\text { Rats after } \mathrm{ZnO} \text { exposure; } \\
\text { BV2 microglial cell line }\end{array}$ & Activate microglia via NFkB, ERK, and $\mathrm{p} 38$ and & Liang et al., 2018 [63] \\
\hline $\begin{array}{l}\text { Peripheral blood mononuclear cells; } \\
\text { RAW } 264.7\end{array}$ & Increase IFN, TNFA, and IL12. Induce ROS & Xia et al.. 2008 [56] \\
\hline \multicolumn{3}{|c|}{ Iron oxide NPs } \\
\hline $\begin{array}{l}\text { RAW } 264.7 \text { macrophages alone or } \\
\text { with cancer cells; adenocarcinoma } \\
\text { mouse model }\end{array}$ & $\begin{array}{l}\text { Up-regulate M1 markers (TNFa, CD86) } \\
\text { and ROS; }\end{array}$ & $\begin{array}{l}\text { Zanganeh et al., } \\
\quad 2016[64]\end{array}$ \\
\hline Melanoma mouse model & $\begin{array}{l}\text { activate Th1 response and anticancer immunity; } \\
\text { reduce tumor growth } \\
\text { induce activation of macrophages and T cells } \\
\text { and maturation of dendritic cells }\end{array}$ & Luo et al., 2019 [65] \\
\hline
\end{tabular}


Table 1. Cont.

\begin{tabular}{|c|c|c|}
\hline Macrophage Cells/ & \multirow{2}{*}{ Functional Effect of Nanoparticles } & \multirow{2}{*}{ Reference } \\
\hline In Vivo Model & & \\
\hline \multicolumn{3}{|c|}{ Titanium oxide NPs } \\
\hline THP1 macrophages & $\begin{array}{l}\text { Increase Il1 } \beta \text { and inflammasome production in } \\
\qquad N F \kappa B \text { dependent mode }\end{array}$ & Fukatsu et al., 2018 [66] \\
\hline $\begin{array}{l}\text { THP1; mouse bone } \\
\text { marrow-derived MФs; }\end{array}$ & $\begin{array}{c}\text { Inflammasome formation, Il } 1 \beta \text { and a release; } \\
\text { lung inflammation }\end{array}$ & Yazdi et al., 2010 [67] \\
\hline \multicolumn{3}{|l|}{ Pulmonary inflammation } \\
\hline Myelomonocytic U-937 cells & Increased TLR3,7,10; no effect on cytokines & $\begin{array}{l}\text { Lucarelli et al., } \\
2004 \text { [68] }\end{array}$ \\
\hline CNS inflammation & Increased ROS and NO production & Wu and Tang, 2017 [69] \\
\hline THP1 macrophages & $\begin{array}{l}\text { Polarize towards M2 (up-regulate arginase 1, } \\
\text { mannose receptor, IL10) via PI3K/Akt } \\
\text { and Erk1/2 }\end{array}$ & Xu et al., 2019 [70] \\
\hline \multicolumn{3}{|c|}{ Copper oxide NPs } \\
\hline $\begin{array}{l}\text { LPS-treated RAW } 264.7 \text { and mouse } \\
\text { bone marrow-derived MФs }\end{array}$ & Inhibit phagocytosis, reduce NO production & $\begin{array}{l}\text { Triboulet et al., } \\
2013 \text { [71] }\end{array}$ \\
\hline Mouse peritonitis model & Recruit MФs & Arancibia et al., 2016 \\
\hline LPS-primed peritoneal MФs & $\begin{array}{l}\text { reduce NO production in an arginase } \\
\text { dependent model }\end{array}$ & \\
\hline Myelomonocytic U-937 cells & $\begin{array}{l}\text { Inhibit CD14 expression, induce } \mathrm{TNF} \alpha \text {, } \\
\text { reduce IL1R } \alpha\end{array}$ & $\begin{array}{l}\text { Lucarelli et al., } \\
\quad 2004[68]\end{array}$ \\
\hline \multicolumn{3}{|c|}{ Lanthanum oxide NPs } \\
\hline Inhalation & Acute airway inflammation & Sisler et al., 2017 [9] \\
\hline \multicolumn{3}{|c|}{ Cobalt oxide NPs } \\
\hline Peripheral macrophages & Increase IFN $\gamma$ and $\mathrm{TNF} \alpha$, attract $\mathrm{CD} 4+$ cells & $\begin{array}{l}\text { Chattopadhyay et al., } \\
2013[73]\end{array}$ \\
\hline
\end{tabular}

\section{Functional Outcome of Nanoparticle-Macrophage Interactions}

\subsection{External Delivery and Further Fate of Nanoparticles}

NPs can be delivered to the body at the systemic and/or local levels (Figure 2). To be distributed in the organism, NPs should be given with water, food or drugs, or via parenteral routes (injections). Both local and systemic NP uptake can be of an uncontrolled environmental origin; however, in this review, only therapeutic applications of nanomaterials are discussed. Locally NPs are introduced via skin contact, inhalation, or a specialized therapeutic delivery such as intraperitoneal injections when NPs are added directly to the peritoneal tumor site [74-76]. Once in the body, NPs are distributed freely, which is possible only in the bloodstream for a limited time, or NPs are engulfed by mononuclear cells or tissue-resident MФs (phagocytosis). Depending on the delivery route, NPs are differentially accumulated in specific organs. First of all, moving with the blood flow, either free or engulfed NPs are accumulated in the heart due to the systemic circulation, although the concentration of NPs in this organ is not the biggest. Locally delivered NPs interact with tissue-resident MФs (alveolar, skin, or others), and the majority of NPs remain within the target site. Further, the inhaled or i.v. injected NPs can penetrate the blood-brain barrier where they contact with brain resident MФs (microglia). Additionally, NPs are always found in the liver and spleen, as in these organs the life span of M $\Phi$, including those loaded with NPs, is over [77]. 


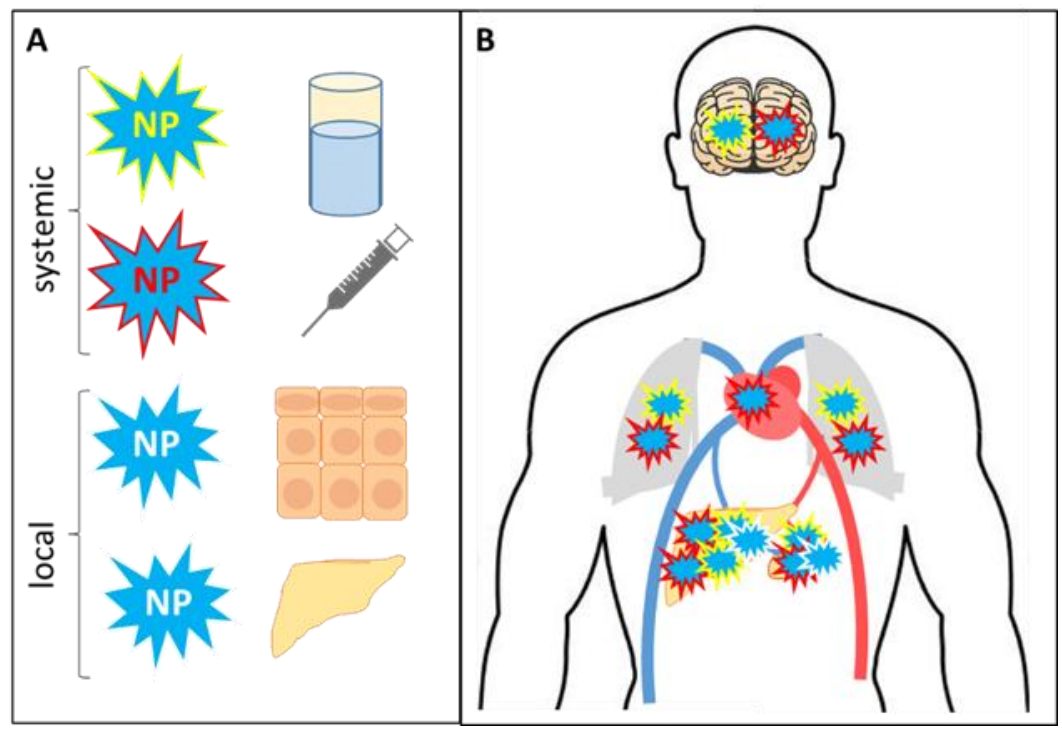

Figure 2. Systemic and local routes of NPs delivery and distribution. (A). At the systemic level, NPs can enter the organism with water/food/drug uptake or i.v. injections. Local contact with NPs occurs from skin contact, inhalation, and tumor therapy. Eventually, NPs are distributed throughout the organism in a cell free form or can be phagocytized. (B). When the phagocytized NPs are moving with the blood flow, they are accumulated in the heart. Air NPs primarily interact with alveolar MФs. Inhaled and injected NPs can penetrate the blood-brain barrier where they contact with microglia. The ultimate destinations of NPs are the liver and the spleen.

\subsection{Macrophages as Nanoparticle Carriers}

MФs are highly active phagocytes that can consume and/or deliver different products, including NPs, to the local inflammatory sites [61]. Also, this 'transportation' property presents MФs as a system to deliver NPs to solid tumors that may be hardly accessible for therapeutic agents due to a dense extracellular matrix or natural barriers. Most of MONPs used in pharmacology are uptaken by MФs via clathrin-mediated endocytosis or pinocytosis and can be found within lysosomes or caveolin-1 and LAMP-1 positive endosomes $[56,78,79]$. Macrophages loaded with iron and tungsten oxide NPs and then injected to the tumor-bearing mice showed a significant antitumor effect in hardly accessible sites [80,81]. Thus, NP transported by M $\Phi$ s provide a sustainable efficacy at the local level, thereby reducing the unfavorable side effects. However, this benefit is eliminated if MФs become activated and release NPs before they reach the tumor so that careful NP design is required.

\subsection{Regulation of Immunity}

Depending on the type of metal and the biological context, MONPs can trigger pro- vs.

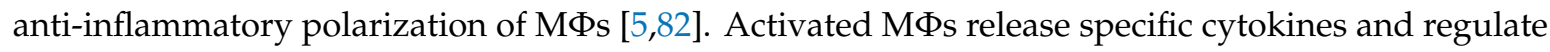
the activity of neutrophils, cytotoxic, or regulatory $\mathrm{T}$ cells, B lymphocytes, as well as non-immune cells (fibroblasts and endothelium). Thus, the interaction of MФs with NPs controls inflammation and regeneration and represents essential immunotherapeutic tools [83]. In particular, the pro-inflammatory effect can be used in cancer therapy when activation and infiltration of immune cells correlate with better clinical prognosis [84]. In particular, the pro-inflammatory effect can be used in cancer therapy when activation and infiltration of immune cells correlate with better clinical prognosis [85]. Moreover, specific FDA approved nanoformulated drugs already showed a promising effect by converting M2-polarized tumor-associated MФs, which promote tumor survival, into M1 [54,64]. For example, carboxymethyl dextran-coated iron oxide NPs Feraheme (also called ferumoxytol) are used for drug delivery to the tumor and direct $\mathrm{M} \Phi$ s towards $\mathrm{M} 1$ to attract cytotoxic $\mathrm{T}$ cells and boost up the antitumor immunity [64]. Other iron and manganese oxide NPs can also enhance antitumor immunity and 
suppress tumor growth and metastasis in a similar way [64,85]. Importantly, specific lymphocyte subsets are individually activated in response to NPs depending on the delivery strategy $[73,86]$. Some NPs, such as nickel oxide, stimulate cytokine eotaxin expression, attract neutrophils and eosinophils to the lungs and cause a severe anaphylactic reaction in mice [87].

All the above data suggest that NPs are involved in pro-inflammatory processes; however, the anti-inflammatory properties of MONPs are also being investigated. MФs treated with LPS or IFN gamma in vitro turned into M1 and showed increased activity of NFKB and STAT1 transcription factors (TFs) and higher production of IL1a, IL6, and TNF alpha. Zinc or cerium MONPs can re-direct MФs towards M2 profile, reducing the secretion of pro-inflammatory cytokines as demonstrated for primary blood monocytes and cell lines $[10,60,88]$. In vivo, $\mathrm{ZnO}$ and TiO NPs significantly reduced acute inflammation in burn wounds, pneumonia, autoimmune, and systemic LPS-driven pathologies $[60-62,89,90]$. These studies show that MONPs not only modulate the functional activity of MФs and other immune subsets but also improve tissue regeneration. One may expect that NPs enhance growth factor production by $\mathrm{M} \Phi \mathrm{s}$, as growth factors are essential for successful recovery in these models. Another mechanism of self-protection is the reduction of $M \Phi$ phagocytic activity demonstrated by iron oxide NPs in ovalbumin-sensitized mice [91]. As the wounds may be associated with hemorrhagia, it is worth noting that NPs may address the problem of bleeding when connected with thrombin; still, the immunoregulatory potential of these NPs is yet to be investigated [92]. Thus, MONPs can support pro- or anti-inflammatory activity of MФs and the immune system in total in a context- and microenvironment-specific mode. This fact reiterates the promising and complex influence of NPs on the immune status. An in-depth understanding of MФ-MONP interactions is required to fully uncover the immunotherapeutic potential of MONPs [60,61].

\subsection{Molecular Mechanisms of Nanoparticle-Mediated Macrophage Polarization}

Besides NPs phagocytosis by MФs, the interaction of NPs with M $\Phi$ surface receptors may be of physiological significance. This interaction activates intracellular signaling pathways of MФs, and phagocytosis is not needed for this activation [67]. Until now, the molecular basis of NP-M $\Phi$ interactions remains unclear due to the diversity of chemical composition and physical properties of NPs and to a variety of cellular contexts [93]. Some researchers classified MФs by the applied stimulus, thereby determining unlimited subsets, e.g., MФs (LPS/IL4/etc). The incentive in vivo is often undetermined, and MФs exhibit mixed M1/2 features [94]. Moreover, the inflammatory microenvironment contains a heterogeneous population of peripheral and resident M $\Phi$ s such as infiltrating monocytes and microglia in CNS $[95,96]$. Accordingly, MФs will present multiple phenotypes following the exposure to various NPs.

In general, the major pro-inflammatory potential of MONPs is mediated by Toll-like receptor (TLR) signaling [97] (Figure 3). The TLR pathway stimulation is an emerging strategy in cancer immunotherapy aimed at obtaining tumor-suppressive $M \Phi s$ and activation of adaptive immunity [98-100]. MONPs exhibit differential potency for TLRs determined by metal type. Indeed, iron oxide NPs up-regulated cytokine production in MФs via TLR2/6, 4, and 8 in a dose-dependent manner [101]. Zinc oxide NPs preferentially interacted with TLR6 in primary mouse MФs; however, other TLRs were also involved. Alternative routes for M $\Phi-N P$ interactions include complement, Fc $\gamma$, and scavenger (SR-A1 and MARCO) receptor pathways. It is likely that the pro-inflammatory effect of NPs requires several cascades since the antagonists of one single receptor failed to abolish inflammation completely [101]. Scavenger receptors participate not only in $M \Phi$ polarization but are responsible for NP uptake; NP phagocytosis is significantly reduced by scavenger receptor ligands heparin, fucoidan, and dextran sulfate [102].

Activation of the lysosomal autophagy system in MФs is required for NP phagocytosis. Accordingly, most NPs are positive regulators of autophagy in MФs (Figure 3). Mainly, TLR4 signaling triggered by NPs results in the upregulation of autophagy markers Sqstm and Lc combined with lysosome formation and accumulation inside the cell [103]. It is known that for iron, cerium, and 
titanium oxide NPs, the TF EB (TFEB), a member of the mTOR pathway, mediates autophagy of MФs [103-107].

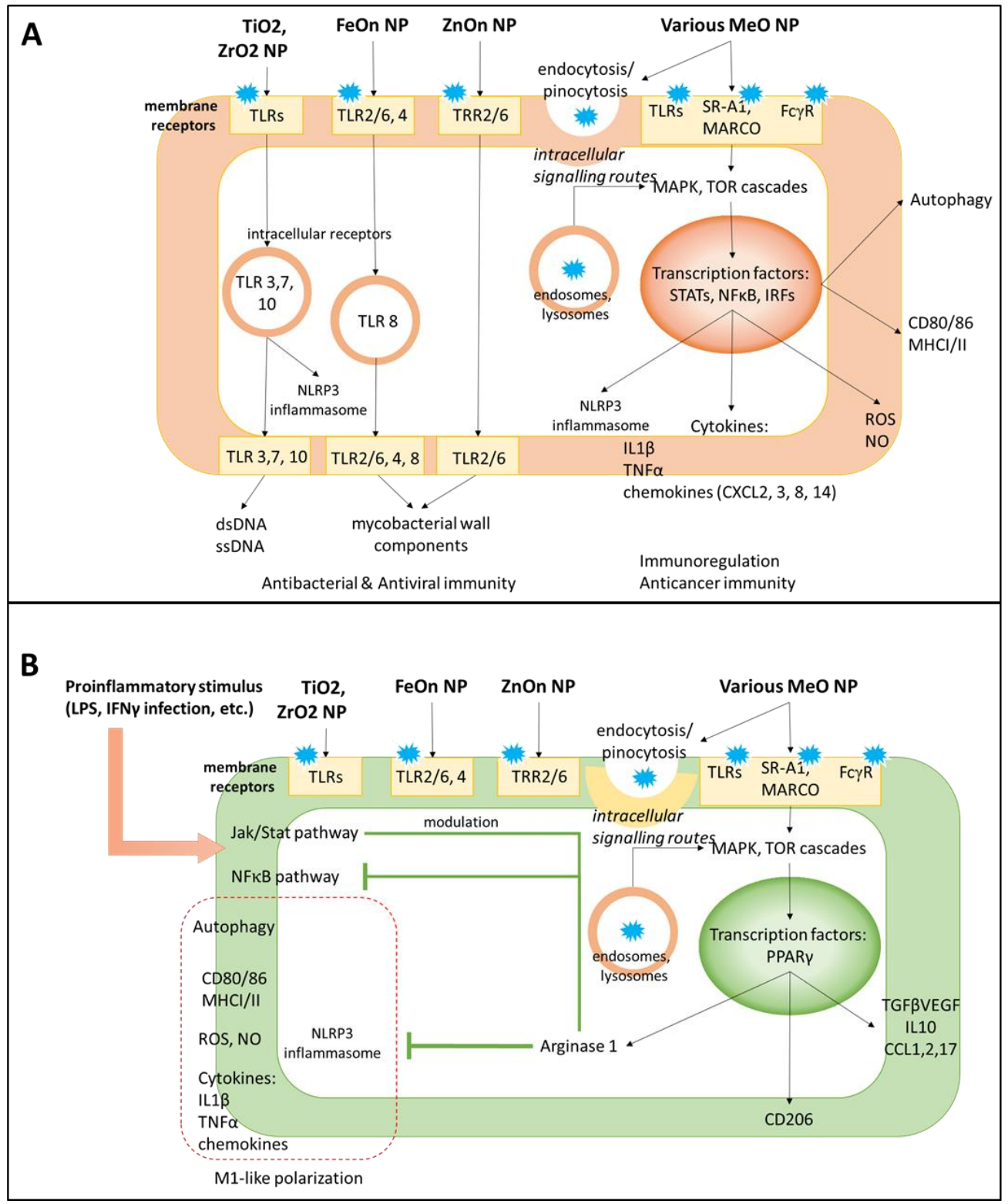

Figure 3. Molecular mechanisms of pro- and anti-inflammatory effects of NPs on MФs. NPs interact with cell surface receptors and can enter the cells via endocytosis/pinocytosis. (A). Pro-inflammatory signaling of NPs activates Toll-like (TLRs), Fc $\gamma$, and SR-A1 and MARCO scavenger receptor pathways with involved downstream MAPK/mTOR cascades and transcription factors STATs, NFkB and IRFs. NPs stimulate cytokine production and release, inflammasome formation, and phagocytic activity, thereby prompting M1 polarization. The immunostimulatory effect of NPs re-shapes the immunosuppressive microenvironment and boosts up antimicrobial or anticancer immunity. (B). The anti-inflammatory activity of NPs is applied to M1 committed MФs, as in chronic inflammatory disorders, autoimmunity, and neurodegeneration. NPs activate transcription factor PPAR $\gamma$ and arginase 1 to inhibit pro-inflammatory NFKB, modulate Jak/STAT pathway, and limit inflammation.

Importantly, while circulating mononuclear cells have to be activated to implement their phagocytic function, the tissue-resident $M \Phi$ s do it routinely to eliminate damaged cells and cell debris, and thus cannot be attributed to resting or M0 [108,109]. This suggests differential activity of TFEB and diverse 


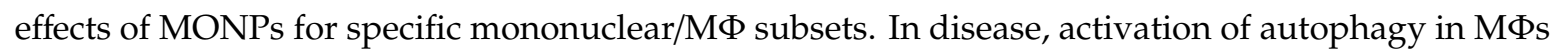
is required for bacteria or virus elimination and can reveal an additional therapeutic application of antioxidant NPs [110,111].

TLRs drive specific signaling in the immunocompetent cells, namely, stimulate the generation of reactive oxygen species (ROS), nitric oxide (NO) and inflammasome production to directly kill pathogens; increase antigen presentation as evident by up-regulated expression of major histocompatibility complex I and II (MHC I, II), CD80, CD86, deliver the cytokines and attract other subpopulations to the inflammatory site. ROS and NO participate in response to the pathogen; however, these species are also considered common markers of NP toxicity and cellular stress in general $[112,113]$. Zhou et al. showed that ROS production is mediated by p53 acetylation and is essential for M1-like polarization in iron-overloaded NPs; a similar mechanism can operate for MONPs [114]. Of interest, individual MONPs induce ROS of different composition and stability, with more active forms generated by $\mathrm{TiO}_{2}$ [115]. Downstream TLR signaling results in activation of MAPK cascades, as inhibitors of ERK, JNK, and p38 protein kinases have been shown to reduce a pro-inflammatory Il1 $\beta$ secretion induced by NPs [116]. Activation of these pathways results in metabolic and functional alterations in MФs including up-regulation of M1 surface marker CD86 and differential expression of pro-inflammatory cytokines (II1 $\beta, \mathrm{TNF} \alpha, \mathrm{IL} 8)$ and chemokines (CXCL8, CXCL2 and 3, CXCL14) [64,111]. When secreted, these cytokines attract other mononuclear/M $\Phi$ cells, neutrophils, as well as adaptive immune subsets ( $\mathrm{T}$ and B lymphocytes, natural killer cells). Activation of TLR4 and autophagy pathways also led to the generation of ROS and NO as mediators of the pro-inflammatory potential in M1 MФs [117,118]. Indeed, MONPs increased ROS and NO levels in MФs [69]. On the other side, ROS and NO production induced by NPs can serve as markers of oxidative stress and cytotoxicity, as their levels correlate with the incidence of cell death [112].

An anti-inflammatory effect of MONPs generally develops as a negative regulator of the ongoing inflammation, such as in chronic inflammatory disorders or after M1 activating stimuli (Table 1) [68,119]. The more prominent potential has been reported for cerium, zinc, and copper oxide NPs that can down-regulate inflammation by targeting blood monocytes or tissue-resident $M \Phi s[8,55,56]$. These NPs reduce the activity of STAT1 and NFKB and production of IL1b, IL6, TNF $\alpha$, in LPS pre-treated monocytes or M $\Phi$-like cell lines (THP 1, RAW 264.7) (Figure 3). Also, i.v. injected cerium oxide NPs reduced cytokine and ROS production in a rat model of sepsis, thereby improving animal survival [120]. Furthermore, NPs can regulate local M $\Phi$ populations, including the brain, liver (Kupffer cells), skin, airway $\mathrm{M} \Phi \mathrm{s}$, by reducing their activation and pro-inflammatory cytokine secretion $[8,55,58,59,62,106,121]$. Interestingly, the work of Wu et al. shows that iron NPs not only mitigated cytokine expression but also attenuated cathepsin B and, thus, inhibited lysosomal secretion in microglia [121].

The effects of MONPs on MФs involve gene transcription regulation [122,123]. The TFs abundant in MФs include M1-associated STAT1 and NFKB, as well as STAT3, STAT6, or peroxisome proliferator-activated receptor- $\gamma$ (PPAR- $\gamma$ ) that are more common for M2 cells (Figure 3) [122,124]. Pro-inflammatory stimuli LPS and IFN $\gamma$ act via TLR4 to trigger STAT1 phosphorylation and up-regulate the expression of STAT1-dependent genes, and its effect is prolonged by MONPs $[125,126]$. In the THP1 monocytic cell line, an NFKB inhibitor attenuated Il1 $\beta$ production induced by TiO2 NPs [66]. The anti-inflammatory potential of NPs is also controlled via NFkB down-regulation [57]. Following TLR signaling, the TFs TFEB and Nrf2 translocate to the nucleus and positively regulate the expression of autophagy-related genes Sqstm1 and LC3 [103,127].

Gene expression analysis reveals other TFs that may respond to NP exposure in a more specific way. The activity of M $\Phi$ TFs Zeb2, Smarca5, and Smarcad1 is regulated by ZnO NPs, but not other MONPs, and TFs specific for other MONPs are expected to be identified [106]. An additional mechanism of transcriptional regulation in MФs can be a Mediator complex that controls RNA polymerase II-mediated gene transcription in a highly specific and context-dependent way. Importantly, Mediator is functionally associated with major pro-inflammatory TFs STAT1 and NFkB [128]. The Mediator's 
kinase module consisting of Med12-13, cyclin C and CDK8/19 is involved in M $\Phi$ profiling in response to NPs; however, their roles in M1/M2 polarization remain to be elucidated [106].

\section{Therapeutic Applications of Nanoparticle-Macrophage Interactions}

\subsection{Nanoparticle-Macrophage System for in Vivo Imaging}

MONPs associated with MФs can penetrate hardly accessible sites for therapeutic and diagnostic purposes. Optical properties allow MONP visualization of various tissues with enhanced contrast. Manganese and iron oxide nanoparticles were used to produce positive and negative contrast, respectively, and were tested in rats to detect the transplanted glioma cells in the brain. Moreover, MONPs can also act as a complex $\mathrm{pH}$-responsible $\mathrm{T}_{1}$ contrast agent in cancer cells as they are sensitive for $\mathrm{pH}$ alterations in tumor microenvironment $[129,130]$. Paramagnetic gadolinium oxide nanoparticles are known to be good contrast agent for both in vivo fluorescence and magnetic resonance imaging [131]. Among the iron oxide, manganese oxide, and gadolinium oxide nanoparticles, the last ones possess the highest MR contrast possibilities [132]. In some applications, hybrid gold/iron oxide nanoparticles are reported to be advanced contrast agents for optical imaging [133].

Subsequently, the MONPs phagocytized by МФs can become essential tools for the detection and monitoring of the inflammatory sites, to which МФs are recruited [134]. Examples are experimental autoimmune encephalitis, a mouse model of multiple sclerosis with relapse-remitting course, and regular accidents of the blood-brain barrier disruption and subsequent progressive neurodegeneration. Iron oxide NPs supplemented with europium for better visualization were detected by magnetic resonance imaging, MRI in the mouse brain only during disease outbreak. Interestingly, MONPs were associated with monocyte/macrophage subset within choroid plexus and, thus, showed the damaged site of the brain and levels of neuroinflammation [135]. Another application is detection of atherosclerotic plaques [136] or lesions of pulmonary inflammation [137], where MФs are routinely present. Importantly, the imaging generally based on the optical properties of MONPs can also be supplemented by fluorescent probe labeling [136].

\subsection{Cooperative Nanoparticle-Macrophage System Applications in Immunotherapy}

The role of MONPs in immunotherapy is rapidly emerging. For instance, iron oxide NPs that have been approved by the Food and Drug Administration (FDA) modulate $M \Phi$ activity and show promising results in cancer immunotherapy [65]. Since metals may exhibit both pro- or anti-inflammatory effects in a context-dependent but hardly controllable way, NPs are often loaded with particular cytokines to

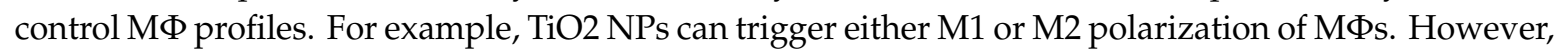
the effect is strictly anti-inflammatory when IL4 is added to the system. Moreover, this combination allows turning M1 into M2 MФs even at the late stage of activation, which is extremely challenging in other systems [138]. Rather than cytokines, NPs used in cancer therapy can carry tumor antigens to activate $M \Phi s$ and $C D 4+/ C D 8+$ cytotoxic T cells against the tumor. To further enhance the therapeutic effect, NPs can be loaded with small interfering RNAs to modulate the immune response or inhibit cancer cell proliferation and survival [139].

Of particular interest are MONPs that can attenuate some side effects of chemotherapy. Indeed, doxorubicin drives M2 M $\Phi$ polarization, thereby increasing the risk of neovascularization, growth factor release, and tumor survival. However, МФs turn into M1, as shown by the increased TNF $\alpha$ production, when loaded with doxorubicin + ZnO NPs [140]. Finally, NPs can significantly improve drug delivery towards solid tumors or metastatic lesions, including CNS, and represent a smart delivery system for precise and efficient immunotherapy [141].

Beyond cancer immunotherapy, NPs may control M $\Phi$ polarization for wound healing in trauma or diabetes [61,142]. There is also an increasing need for NPs tailor-suited for both diagnostic and therapeutic applications (see also Nanoparticle-macrophage system for in vivo imaging). One example comes from gold iron oxide NPs coupled with an anti-CD163 antibody for MRI detection of activated 
MФs in atherosclerotic lesions or inflamed kidneys and, in perspective, for selective control of $M \Phi$ subsets [143,144].

Nevertheless, cytotoxicity remains a major concern in the manufacturing and therapeutic applications of NPs and have to be addressed in the future [5]. Toxicity depends on the metal type, structural properties, and the dose of exposure [9,145-147]. The conventional approach to eliminate cytotoxicity is to combine different metals to maximize the desired therapeutic effect while minimizing off-target oxidative stress and cell death. For example, a combination of copper with $\mathrm{ZnO}$ NPs reduces apoptosis in MФs RAW264.7 [148]. Moreover, a combination of different metal ions may help to control MФ activation and inflammation [149]. Magnesium added to $\mathrm{TiO}_{2}$ down-regulated the expression of pro-inflammatory markers $\mathrm{TNF} \alpha$, IL6, and IL1 $\beta$ and up-regulated the anti-inflammatory CD163 in LPS-primed MФs [150]. $\mathrm{TiO}_{2}$ NPs doped with Ag evoked more pronounced toxicity towards the tumor, but not non-malignant cells, compared to $\mathrm{TiO}_{2}$ alone [151]. The potency of NPs against tumor cells helps to overcome a non-specific activity of NPs in the sites of accumulation [113] (Figure 2).

\title{
6. Future Directions and Conclusions
}

MONPs as drugs alone or drug carriers have proved their efficacy in a variety of biomedical applications. A new attractive area that goes beyond these situations is a cooperation between MONPs and their cellular hosts. MФs, whose primary biological function is phagocytosis, are a perfect target for exogenous nanobiomaterials. This immanent property is advantageous for engineering MФs with various MONPs to produce a controlled tool for powerful immunoregulation at local and systemic levels and is of particular importance for delivery to hardly accessible sites as CNS or tumor [81]. MONPs are expected to properly polarize $M \Phi$ into a pro- or anti-inflammatory phenotype to optimize the immune function for the antitumor response, prevention of autoimmunity, and control of tissue architectonics. Given that M $\Phi$ s loaded with magnetic NPs can be visualized and localized to the desired site using external equipment, MФs-MONPs paradigm emerges as a novel strategy for immunotherapeutic interventions in disease.

Author Contributions: Conceptualization, M.S.D. and A.Y.P.; Writing-Original Draft Preparation, M.S.D. and A.Y.P.; Writing-Review \& Editing, M.S.D., A.A.S. and V.V.V.; Visualization, M.S.D.; Supervision, A.A.S., and V.V.V.

Funding: This research was funded by the Russian Foundation for Basic Research Grant number 19-315-60012.

Acknowledgments: Authors thank the Russian Science Foundation (RSCF) that have supported the experimental work of Vinogradov V.V. and Prilepskii A.Y. on nanoparticles (grant NO 16-13-00041).

Conflicts of Interest: The authors declare no conflict of interest.

\section{Abbreviations}

\author{
IL Interleukin \\ IFN $\gamma$ Interferon gamma \\ LPS Lipopolysaccharide \\ MO Metal oxide \\ M $\Phi$ Macrophage \\ MRI Magnetic resonance imaging \\ NO Nitric oxide \\ NP Nanoparticle \\ ROS Reactive oxygen species \\ TF Transcription factor \\ TLR Toll-like receptor
}

\section{References}

1. Stankic, S.; Suman, S.; Haque, F.; Vidic, J. Pure and multi metal oxide nanoparticles: Synthesis, antibacterial and cytotoxic properties. J. Nanobiotechnol. 2016, 14, 73. [CrossRef] [PubMed] 
2. Zikalala, N.; Matshetshe, K.; Parani, S.; Oluwafemi, O.S. Biosynthesis protocols for colloidal metal oxide nanoparticles. Nano Struct. Nano Objects 2018, 16, 288-299. [CrossRef]

3. Bharde, A.; Rautaray, D.; Bansal, V.; Ahmad, A.; Sarkar, I.; Yusuf, S.M.; Sanyal, M.; Sastry, M. Extracellular biosynthesis of magnetite using fungi. Small 2006, 2, 135-141. [CrossRef] [PubMed]

4. Peralta-Videa, J.R.; Huang, Y.; Parsons, J.G.; Zhao, L.; Lopez-Moreno, L.; Hernandez-Viezcas, J.A.; Gardea-Torresdey, J.L. Plant-based green synthesis of metallic nanoparticles: Scientific curiosity or a realistic alternative to chemical synthesis? Nanotechnol. Environ. Eng. 2016, 1, 4. [CrossRef]

5. Mirshafiee, V.; Sun, B.; Chang, C.H.; Liao, Y.-P.; Jiang, W.; Jiang, J.; Liu, X.; Wang, X.; Xia, T.; Nel, A.E. Toxicological Profiling of Metal Oxide Nanoparticles in Liver Context Reveals Pyroptosis in Kupffer Cells and Macrophages versus Apoptosis in Hepatocytes. ACS Nano 2018, 12, 3836-3852. [CrossRef] [PubMed]

6. Rutenberg, A.; Vinogradov, V.V.; Avnir, D. Synthesis and enhanced thermal stability of albumins@alumina: Towards injectable sol-gel materials. Chem. Commun. 2013, 49, 5636-5638. [CrossRef] [PubMed]

7. Solovev, Y.V.; Prilepskii, A.Y.; Krivoshapkina, E.F.; Fakhardo, A.F.; Bryushkova, E.A.; Kalikina, P.A.; Koshel, E.I.; Vinogradov, V.V. Sol-gel derived boehmite nanostructures is a versatile nanoplatform for biomedical applications. Sci. Rep. 2019, 9, 1. [CrossRef]

8. Oró, D.; Yudina, T.; Fernández-Varo, G.; Casals, E.; Reichenbach, V.; Casals, G.; González de la Presa, B.; Sandalinas, S.; Carvajal, S.; Puntes, V.; et al. Cerium oxide nanoparticles reduce steatosis, portal hypertension and display anti-inflammatory properties in rats with liver fibrosis. J. Hepatol. 2016, 64, 691-698. [CrossRef]

9. Sisler, J.D.; Li, R.; McKinney, W.; Mercer, R.R.; Ji, Z.; Xia, T.; Wang, X.; Shaffer, J.; Orandle, M.; Mihalchik, A.L.; et al. Differential pulmonary effects of $\mathrm{CoO}$ and $\mathrm{La}_{2} \mathrm{O}_{3}$ metal oxide nanoparticle responses during aerosolized inhalation in mice. Part. Fibre Toxicol. 2016, 13, 42. [CrossRef]

10. Antonoglou, O.; Lafazanis, K.; Mourdikoudis, S.; Vourlias, G.; Lialiaris, T.; Pantazaki, A.; Dendrinou-Samara, C. Biological relevance of $\mathrm{CuFeO}_{2}$ nanoparticles: Antibacterial and anti-inflammatory activity, genotoxicity, DNA and protein interactions. Mater. Sci. Eng. C 2019, 99, 264-274. [CrossRef]

11. Drozdov, A.S.; Ivanovski, V.; Avnir, D.; Vinogradov, V.V. A universal magnetic ferrofluid: Nanomagnetite stable hydrosol with no added dispersants and at neutral pH. J. Colloid Interface Sci. 2016, 468, 307-312. [CrossRef] [PubMed]

12. Serov, N.; Prilepskii, A.; Sokolov, A.; Vinogradov, V. Synthesis of Plasmin-Loaded $\mathrm{Fe}_{3} \mathrm{O}_{4} @ \mathrm{CaCO}_{3}$ Nanoparticles: Towards Next-Generation Thrombolytic Drugs. ChemNanoMat 2019, 5, 1267-1271. [CrossRef]

13. Oyewumi, M.O.; Yokel, R.A.; Jay, M.; Coakley, T.; Mumper, R.J. Comparison of cell uptake, biodistribution and tumor retention of folate-coated and PEG-coated gadolinium nanoparticles in tumor-bearing mice. $J$. Control. Release 2004, 95, 613-626. [CrossRef] [PubMed]

14. Maggiorella, L.; Barouch, G.; Devaux, C.; Pottier, A.; Deutsch, E.; Bourhis, J.; Borghi, E.; Levy, L. Nanoscale radiotherapy with hafnium oxide nanoparticles. Futur. Oncol. 2012, 8, 1167-1181. [CrossRef] [PubMed]

15. Srivastava, V.; Sharma, Y.C.; Sillanpää, M. Green synthesis of magnesium oxide nanoflower and its application for the removal of divalent metallic species from synthetic wastewater. Ceram. Int. 2015, 41, 6702-6709. [CrossRef]

16. Zhang, M.; Cao, Y.; Wang, L.; Ma, Y.; Tu, X.; Zhang, Z. Manganese doped iron oxide theranostic nanoparticles for combined $T_{1}$ magnetic resonance imaging and photothermal therapy. ACS Appl. Mater. Interfaces 2015, 7, 4650-4658. [CrossRef]

17. Vinogradov, A.V.; Vinogradov, V.V. Low-temperature sol-gel synthesis of crystalline materials. RSC Adv. 2014, 4, 45903-45919. [CrossRef]

18. Roy, R.; Parashar, V.; Chauhan, L.K.S.; Shanker, R.; Das, M.; Tripathi, A.; Dwivedi, P.D. Mechanism of uptake of $\mathrm{ZnO}$ nanoparticles and inflammatory responses in macrophages require PI3K mediated MAPKs signaling. Toxicol. Vitr. 2014, 28, 457-467. [CrossRef]

19. Rajeshkumar, S.; Naik, P. Synthesis and biomedical applications of Cerium oxide nanoparticles-A Review. Biotechnol. Rep. 2018, 17, 1-5. [CrossRef]

20. D’Angelo, B.; Santucci, S.; Benedetti, E.; Di Loreto, S.; Phani, R.; Falone, S.; Amicarelli, F.; Ceru, M.; Cimini, A. Cerium Oxide Nanoparticles Trigger Neuronal Survival in a Human Alzheimer Disease Model by Modulating BDNF Pathway. Curr. Nanosci. 2009, 5, 167-176. [CrossRef]

21. Nelson, B.C.; Johnson, M.E.; Walker, M.L.; Riley, K.R.; Sims, C.M. Antioxidant cerium oxide nanoparticles in biology and medicine. Antioxidants 2016, 5, 15. [CrossRef] [PubMed] 
22. Munusamy, S.; Bhakyaraj, K.; Vijayalakshmi, L.; Stephen, A.; Narayanan, V. Synthesis and characterization of cerium oxide nanoparticles using Curvularia lunata and their antibacterial properties. Int. J. Innov. Res. Sci. Eng. 2014, 12, 1401-1413.

23. Okuda, M.; Suzumoto, Y.; Yamashita, I. Bioinspired synthesis of homogenous cerium oxide nanoparticles and two- or three-dimensional nanoparticle arrays using protein supramolecules. Cryst. Growth Des. 2011, 11, 2540-2545. [CrossRef]

24. Arumugam, A.; Karthikeyan, C.; Haja Hameed, A.S.; Gopinath, K.; Gowri, S.; Karthika, V. Synthesis of cerium oxide nanoparticles using Gloriosa superba L. leaf extract and their structural, optical and antibacterial properties. Mater. Sci. Eng. C 2015, 49, 408-415. [CrossRef] [PubMed]

25. Kannan, S.K.; Sundrarajan, M. A green approach for the synthesis of a cerium oxide nanoparticle: Characterization and antibacterial activity. Int. J. Nanosci. 2014, 13, 1450018. [CrossRef]

26. Pugazhendhi, A.; Prabhu, R.; Muruganantham, K.; Shanmuganathan, R.; Natarajan, S. Anticancer, antimicrobial and photocatalytic activities of green synthesized magnesium oxide nanoparticles (MgONPs) using aqueous extract of Sargassum wightii. J. Photochem. Photobiol. B Biol. 2019, 190, 86-97. [CrossRef]

27. Mayedwa, N.; Mongwaketsi, N.; Khamlich, S.; Kaviyarasu, K.; Matinise, N.; Maaza, M. Green synthesis of nickel oxide, palladium and palladium oxide synthesized via Aspalathus linearis natural extracts: Physical properties \& mechanism of formation. Appl. Surf. Sci. 2018, 446, 266-272.

28. Siddiqi, K.S.; ur Rahman, A.; Husen, A. Properties of Zinc Oxide Nanoparticles and Their Activity Against Microbes. Nanoscale Res. Lett. 2018, 13, 141. [CrossRef]

29. Espitia, P.J.P.; Soares, N.D.F.F.; dos Reis Coimbra, J.S.; de Andrade, N.J.; Cruz, R.S.; Medeiros, E.A.A. Zinc Oxide Nanoparticles: Synthesis, Antimicrobial Activity and Food Packaging Applications. Food Bioprocess Technol. 2012, 5, 1447-1464. [CrossRef]

30. Aghababazadeh, R.; Mazinani, B.; Mirhabibi, A.; Tamizifar, M. ZnO Nanoparticles Synthesised by mechanochemical processing. J. Phys. Conf. Ser. 2006, 26, 312-314. [CrossRef]

31. Swihart, M.T. Vapor-phase synthesis of nanoparticles. Curr. Opin. Colloid Interface Sci. 2003, 8, 127-133. [CrossRef]

32. Lu, P.J.; Huang, S.C.; Chen, Y.P.; Chiueh, L.C.; Shih, D.Y.C. Analysis of titanium dioxide and zinc oxide nanoparticles in cosmetics. J. Food Drug Anal. 2015, 23, 587-594. [CrossRef] [PubMed]

33. Prilepskii, A.Y.; Fakhardo, A.F.; Drozdov, A.S.; Vinogradov, V.V.; Dudanov, I.P.; Shtil, A.A.; Bel'Tyukov, P.P.; Shibeko, A.M.; Koltsova, E.M.; Nechipurenko, D.Y.; et al. Urokinase-Conjugated Magnetite Nanoparticles as a Promising Drug Delivery System for Targeted Thrombolysis: Synthesis and Preclinical Evaluation. ACS Appl. Mater. Interfaces 2018, 10, 36764-36775. [CrossRef] [PubMed]

34. Fantechi, E.; Innocenti, C.; Albino, M.; Lottini, E.; Sangregorio, C. Influence of cobalt doping on the hyperthermic efficiency of magnetite nanoparticles. J. Magn. Magn. Mater. 2015, 380, 365-371. [CrossRef]

35. Bullivant, J.P.; Zhao, S.; Willenberg, B.J.; Kozissnik, B.; Batich, C.D.; Dobson, J. Materials characterization of feraheme/ferumoxytol and preliminary evaluation of its potential for magnetic fluid hyperthermia. Int. J. Mol. Sci. 2013, 14, 17501-17510. [CrossRef]

36. Nuzhina, J.V.; Shtil, A.A.; Prilepskii, A.Y.; Vinogradov, V.V. Preclinical Evaluation and Clinical Translation of Magnetite-Based Nanomedicines. J. Drug Deliv. Sci. Technol. 2019, 54, 101282. [CrossRef]

37. Pemandu, J. Economic Transformation Programme (ETP): Annual Report 2014 Review. ETP Handb. 2010, 513-550.

38. Polischuk, S.D.; Churilov, G.I.; Borychev, S.N.; Byshov, N.V.; Nazarova, A.A. Nanopowders of cuprum, cobalt and their oxides used in the intensive technology for growing cucumbers. Int. J. Nanotechnol. 2018, 15, 352-369.

39. Churilova, V.V.; Nazarova, A.A.; Polishchuk, S.D. Influence of Biodrugs with Nanoparticles of Ferrum, Cobalt and Cuprum on Growth, Development, Yield and Phytohormone Status of Fodder and Red Beets. Nano Hybrids Compos. 2017, 13, 149-155. [CrossRef]

40. Rizwan, M.; Ali, S.; Qayyum, M.F.; Ok, Y.S.; Adrees, M.; Ibrahim, M.; Zia-ur-Rehman, M.; Farid, M.; Abbas, F. Effect of metal and metal oxide nanoparticles on growth and physiology of globally important food crops: A critical review. J. Hazard. Mater. 2017, 322, 2-16. [CrossRef]

41. Alinovi, R.; Goldoni, M.; Pinelli, S.; Campanini, M.; Aliatis, I.; Bersani, D.; Lottici, P.P.; Iavicoli, S.; Petyx, M.; Mozzoni, P.; et al. Oxidative and pro-inflammatory effects of cobalt and titanium oxide nanoparticles on aortic and venous endothelial cells. Toxicol. Vitr. 2015, 29, 426-437. [CrossRef] [PubMed] 
42. Nosrati, H.; Sefidi, N.; Sharafi, A.; Danafar, H.; Kheiri Manjili, H. Bovine Serum Albumin (BSA) coated iron oxide magnetic nanoparticles as biocompatible carriers for curcumin-anticancer drug. Bioorg. Chem. 2018, 76, 501-509. [CrossRef] [PubMed]

43. Chen, X.; Gao, C. Influences of surface coating of PLGA nanoparticles on immune activation of macrophages. J. Mater. Chem. B 2018, 6, 2065-2077. [CrossRef]

44. Lee, Y.K.; Choi, E.J.; Webster, T.J.; Kim, S.H.; Khang, D. Effect of the protein corona on nanoparticles for modulating cytotoxicity and immunotoxicity. Int. J. Nanomed. 2014, 10, 97-113.

45. Ke, P.C.; Lin, S.; Parak, W.J.; Davis, T.P.; Caruso, F. A Decade of the Protein Corona. ACS Nano 2017, 11, 11773-11776. [CrossRef] [PubMed]

46. Falcaro, P.; Ricco, R.; Yazdi, A.; Imaz, I.; Furukawa, S.; Maspoch, D.; Ameloot, R.; Evans, J.D.; Doonan, C.J. Application of metal and metal oxide nanoparticles at MOFs. Coord. Chem. Rev. 2016, 307, 237-254. [CrossRef]

47. Mingabudinova, L.R.; Vinogradov, V.V.; Milichko, V.A.; Hey-Hawkins, E.; Vinogradov, A.V. Metal-organic frameworks as competitive materials for non-linear optics. Chem. Soc. Rev. 2016, 45, 5408-5431. [CrossRef]

48. Ginhoux, F.; Guilliams, M. Tissue-Resident Macrophage Ontogeny and Homeostasis. Immunity 2016, 44, 439-449. [CrossRef]

49. Carestia, A.; Mena, H.A.; Olexen, C.M.; Ortiz Wilczyñski, J.M.; Negrotto, S.; Errasti, A.E.; Gómez, R.M.; Jenne, C.N.; Carrera Silva, E.A.; Schattner, M. Platelets Promote Macrophage Polarization toward Pro-inflammatory Phenotype and Increase Survival of Septic Mice. Cell Rep. 2019, 28, 896-908. [CrossRef]

50. Bogen, B.; Fauskanger, M.; Haabeth, O.A.; Tveita, A. CD4+ T cells indirectly kill tumor cells via induction of cytotoxic macrophages in mouse models. Cancer Immunol. Immunother. 2019, 68, 1865-1873. [CrossRef]

51. Laviron, M.; Boissonnas, A. Ontogeny of Tumor-Associated Macrophages. Front. Immunol. 2019, 10, 1799. [CrossRef] [PubMed]

52. Lozano-Fernández, T.; Ballester-Antxordoki, L.; Pérez-Temprano, N.; Rojas, E.; Sanz, D.; Iglesias-Gaspar, M.; Moya, S.; González-Fernández, Á.; Rey, M. Potential impact of metal oxide nanoparticles on the immune system: The role of integrins, L-selectin and the chemokine receptor CXCR4. Nanomed. Nanotechnol. Biol. Med. 2014, 10, 1301-1310. [CrossRef] [PubMed]

53. Harrison, P.; Martin Cramer, E. Platelet $\alpha$-granules. Blood Rev. 1993, 7, 52-62. [CrossRef]

54. Reichel, D.; Tripathi, M.; Perez, J.M. Biological Effects of Nanoparticles on Macrophage Polarization in the Tumor Microenvironment. Nanotheranostics 2019, 3, 66-88. [CrossRef] [PubMed]

55. Selvaraj, V.; Nepal, N.; Rogers, S.; Manne, N.D.P.K.; Arvapalli, R.; Rice, K.M.; Asano, S.; Fankhanel, E.; $\mathrm{Ma}$, J.J.; Shokuhfar, T.; et al. Inhibition of MAP kinase/NF-kB mediated signaling and attenuation of lipopolysaccharide induced severe sepsis by cerium oxide nanoparticles. Biomaterials 2015, 59, 160-171. [CrossRef]

56. Xia, T.; Kovochich, M.; Liong, M.; Mädler, L.; Gilbert, B.; Shi, H.; Yeh, J.I.; Zink, J.I.; Nel, A.E. Comparison of the mechanism of toxicity of zinc oxide and cerium oxide nanoparticles based on dissolution and oxidative stress properties. ACS Nano 2008, 2, 2121-2134. [CrossRef]

57. Kim, M.; Jeong, H. Zinc Oxide Nanoparticles Suppress LPS-Induced NF-кB Activation by Inducing A20, a Negative Regulator of NF-kB, in RAW 264.7 Macrophages. J. Nanosci. Nanotechnol. 2015, 15, 6509-6515. [CrossRef]

58. Makumire, S.; Chakravadhanula, V.S.K.; Köllisch, G.; Redel, E.; Shonhai, A. Immunomodulatory activity of zinc peroxide $\left(\mathrm{ZnO}_{2}\right)$ and titanium dioxide $\left(\mathrm{TiO}_{2}\right)$ nanoparticles and their effects on DNA and protein integrity. Toxicol. Lett. 2014, 227, 56-64. [CrossRef]

59. Lin, C.-D.; Kou, Y.-Y.; Liao, C.-Y.; Li, C.-H.; Huang, S.-P.; Cheng, Y.-W.; Liao, W.-C.; Chen, H.-X.; Wu, P.-L.; Kang, J.-J.; et al. Zinc oxide nanoparticles impair bacterial clearance by macrophages. Nanomedicine 2014, 9, 1327-1339. [CrossRef]

60. Ali, S.S.; Morsy, R.; El-Zawawy, N.A.; Fareed, M.F.; Bedaiwy, M.Y. Synthesized zinc peroxide nanoparticles ( $\mathrm{ZnO}_{2}$-NPs): A novel antimicrobial, anti-elastase, anti-keratinase, and anti-inflammatory approach toward polymicrobial burn wounds. Int. J. Nanomed. 2017, 12, 6059-6073. [CrossRef]

61. Seisenbaeva, G.A.; Fromell, K.; Vinogradov, V.V.; Terekhov, A.N.; Pakhomov, A.V.; Nilsson, B.; Ekdahl, K.N.; Vinogradov, V.V.; Kessler, V.G. Dispersion of $\mathrm{TiO}_{2}$ nanoparticles improves burn wound healing and tissue regeneration through specific interaction with blood serum proteins. Sci. Rep. 2017, 7, 15448. [CrossRef] [PubMed] 
62. Ilves, M.; Palomäki, J.; Vippola, M.; Lehto, M.; Savolainen, K.; Savinko, T.; Alenius, H. Topically applied ZnO nanoparticles suppress allergen induced skin inflammation but induce vigorous IgE production in the atopic dermatitis mouse model. Part. Fibre Toxicol. 2014, 11, 38. [CrossRef] [PubMed]

63. Liang, H.; Chen, A.; Lai, X.; Liu, J.; Wu, J.; Kang, Y.; Wang, X.; Shao, L. Neuroinflammation is induced by tongue-instilled $\mathrm{ZnO}$ nanoparticles via the $\mathrm{Ca}^{2+}$-dependent NF-kB and MAPK pathways. Part. Fibre Toxicol. 2018, 15, 39. [CrossRef] [PubMed]

64. Zanganeh, S.; Hutter, G.; Spitler, R.; Lenkov, O.; Mahmoudi, M.; Shaw, A.; Pajarinen, J.S.; Nejadnik, H.; Goodman, S.; Moseley, M.; et al. Iron oxide nanoparticles inhibit tumour growth by inducing pro-inflammatory macrophage polarization in tumour tissues. Nat. Nanotechnol. 2016, 11, 986-994. [CrossRef] [PubMed]

65. Luo, L.; Iqbal, M.Z.; Liu, C.; Xing, J.; Akakuru, O.U.; Fang, Q.; Li, Z.; Dai, Y.; Li, A.; Guan, Y.; et al. Engineered nano-immunopotentiators efficiently promote cancer immunotherapy for inhibiting and preventing lung metastasis of melanoma. Biomaterials 2019, 223, 119464. [CrossRef] [PubMed]

66. Fukatsu, H.; Koide, N.; Tada-Oikawa, S.; Izuoka, K.; Ikegami, A.; Ichihara, S.; Umezawa, K. NF-kB inhibitor DHMEQ inhibits titanium dioxide nanoparticle-induced interleukin- $1 \beta$ production: Inhibition of the PM2.5-induced inflammation model. Mol. Med. Rep. 2018, 18, 5279-5285. [CrossRef] [PubMed]

67. Yazdi, A.S.; Guarda, G.; Riteau, N.; Drexler, S.K.; Tardivel, A.; Couillin, I.; Tschopp, J. Nanoparticles activate the NLR pyrin domain containing 3 (Nlrp3) inflammasome and cause pulmonary inflammation through release of IL-1 $\alpha$ and IL-1ß. Proc. Natl. Acad. Sci. USA 2010, 107, 19449-19454. [CrossRef]

68. Lucarelli, M.; Gatti, A.; Savarino, G.; Quattroni, P.; Martinelli, L.; Monari, E.; Boraschi, D. Innate defence functions of macrophages can be biased by nano-sized ceramic and metallic particles. Eur. Cytokine Netw. 2004, 15, 339-346.

69. Wu, T.; Tang, M. The inflammatory response to silver and titanium dioxide nanoparticles in the central nervous system. Nanomedicine 2018, 13, 233-249. [CrossRef]

70. Xu, W.-C.; Dong, X.; Ding, J.-L.; Liu, J.-C.; Xu, J.-J.; Tang, Y.-H.; Yi, Y.-P.; Lu, C.; Yang, W.; Yang, J.-S.; et al. Nanotubular $\mathrm{TiO}_{2}$ regulates macrophage M2 polarization and increases macrophage secretion of VEGF to accelerate endothelialization via the ERK1/2 and PI3K/AKT pathways. Int. J. Nanomed. 2019, 14, 441-455. [CrossRef]

71. Triboulet, S.; Aude-Garcia, C.; Carrière, M.; Diemer, H.; Proamer, F.; Habert, A.; Chevallet, M.; Collin-Faure, V.; Strub, J.-M.; Hanau, D.; et al. Molecular responses of mouse macrophages to copper and copper oxide nanoparticles inferred from proteomic analyses. Mol. Cell. Proteom. 2013, 12, 3108-3122. [CrossRef] [PubMed]

72. Arancibia, S.; Barrientos, A.; Torrejón, J.; Escobar, A.; Beltrán, C.J. Copper oxide nanoparticles recruit macrophages and modulate nitric oxide, proinflammatory cytokines and PGE2 production through arginase activation. Nanomedicine 2016, 11, 1237-1251. [CrossRef] [PubMed]

73. Chattopadhyay, S.; Dash, S.K.; Ghosh, T.; Das, S.; Tripathy, S.; Mandal, D.; Das, D.; Pramanik, P.; Roy, S. Anticancer and immunostimulatory role of encapsulated tumor antigen containing cobalt oxide nanoparticles. JBIC J. Biol. Inorg. Chem. 2013, 18, 957-973. [CrossRef] [PubMed]

74. Gao, N.; Bozeman, E.N.; Qian, W.; Wang, L.; Chen, H.; Lipowska, M.; Staley, C.A.; Wang, Y.A.; Mao, H.; Yang, L. Tumor Penetrating Theranostic Nanoparticles for Enhancement of Targeted and Image-guided Drug Delivery into Peritoneal Tumors following Intraperitoneal Delivery. Theranostics 2017, 7, 1689-1704. [CrossRef] [PubMed]

75. Mehta, M.; Deeksha; Sharma, N.; Vyas, M.; Khurana, N.; Maurya, P.K.; Singh, H.; Andreoli de Jesus, T.P.; Dureja, H.; Chellappan, D.K.; et al. Interactions with the macrophages: An emerging targeted approach using novel drug delivery systems in respiratory diseases. Chem. Biol. Interact. 2019, 304, 10-19.

76. Shakil, M.; Hasan, M.; Sarker, S. Iron Oxide Nanoparticles for Breast Cancer Theranostics. Curr. Drug Metab. 2019, 20, 446-456. [CrossRef]

77. Mohammadi, M.R.; Malkovskiy, A.V.; Jothimuthu, P.; Kim, K.-M.; Parekh, M.; Inayathullah, M.; Zhuge, Y.; Rajadas, J. PEG/Dextran Double Layer Influences Fe Ion Release and Colloidal Stability of Iron Oxide Nanoparticles. Sci. Rep. 2018, 8, 4286. [CrossRef]

78. Walkey, C.D.; Olsen, J.B.; Guo, H.; Emili, A.; Chan, W.C.W. Nanoparticle Size and Surface Chemistry Determine Serum Protein Adsorption and Macrophage Uptake. J. Am. Chem. Soc. 2012, 134, 2139-2147. [CrossRef] 
79. Vanhecke, D.; Kuhn, D.A.; Jimenez de Aberasturi, D.; Balog, S.; Milosevic, A.; Urban, D.; Peckys, D.; de Jonge, N.; Parak, W.J.; Petri-Fink, A.; et al. Involvement of two uptake mechanisms of gold and iron oxide nanoparticles in a co-exposure scenario using mouse macrophages. Beilstein J. Nanotechnol. 2017, 8 , 2396-2409. [CrossRef]

80. Zheng, B.; Bai, Y.; Chen, H.; Pan, H.; Ji, W.; Gong, X.; Wu, X.; Wang, H.; Chang, J. Targeted delivery of tungsten oxide nanoparticles for multifunctional anti-tumor therapy via macrophages. Biomater. Sci. 2018, 6, 1379-1389. [CrossRef]

81. Dalzon, B.; Guidetti, M.; Testemale, D.; Reymond, S.; Proux, O.; Vollaire, J.; Collin-Faure, V.; Testard, I.; Fenel, D.; Schoehn, G.; et al. Utility of macrophages in an antitumor strategy based on the vectorization of iron oxide nanoparticles. Nanoscale 2019, 11, 9341-9352. [CrossRef] [PubMed]

82. Agoro, R.; Taleb, M.; Quesniaux, V.F.J.; Mura, C. Cell iron status influences macrophage polarization. PLoS ONE 2018, 13, e0196921. [CrossRef] [PubMed]

83. Goldberg, M.S. Improving cancer immunotherapy through nanotechnology. Nat. Rev. Cancer 2019, 19, 587-602. [CrossRef] [PubMed]

84. Shao, K.; Singha, S.; Clemente-Casares, X.; Tsai, S.; Yang, Y.; Santamaria, P. Nanoparticle-Based Immunotherapy for Cancer. ACS Nano 2015, 9, 16-30. [CrossRef] [PubMed]

85. Liang, R.; Liu, L.; He, H.; Chen, Z.; Han, Z.; Luo, Z.; Wu, Z.; Zheng, M.; Ma, Y.; Cai, L. Oxygen-boosted immunogenic photodynamic therapy with gold nanocages@manganese dioxide to inhibit tumor growth and metastases. Biomaterials 2018, 177, 149-160. [CrossRef] [PubMed]

86. Neto, L.M.M.; Zufelato, N.; de Sousa-Júnior, A.A.; Trentini, M.M.; da Costa, A.C.; Bakuzis, A.F.; Kipnis, A.; Junqueira-Kipnis, A.P. Specific T cell induction using iron oxide based nanoparticles as subunit vaccine adjuvant. Hum. Vaccin. Immunother. 2018, 14, 2786-2801. [CrossRef] [PubMed]

87. Lee, S.; Hwang, S.-H.; Jeong, J.; Han, Y.; Kim, S.-H.; Lee, D.-K.; Lee, H.-S.; Chung, S.-T.; Jeong, J.; Roh, C.; et al. Nickel oxide nanoparticles can recruit eosinophils in the lungs of rats by the direct release of intracellular eotaxin. Part. Fibre Toxicol. 2016, 13, 30. [CrossRef]

88. Nagajyothi, P.C.; Cha, S.J.; Yang, I.J.; Sreekanth, T.V.M.; Kim, K.J.; Shin, H.M. Antioxidant and anti-inflammatory activities of zinc oxide nanoparticles synthesized using Polygala tenuifolia root extract. $J$. Photochem. Photobiol. B Biol. 2015, 146, 10-17. [CrossRef]

89. Serebrovska, Z.; Swanson, R.J.; Portnichenko, V.; Shysh, A.; Pavlovich, S.; Tumanovska, L.; Dorovskych, A.; Lysenko, V.; Tertykh, V.; Bolbukh, Y.; et al. Anti-inflammatory and antioxidant effect of cerium dioxide nanoparticles immobilized on the surface of silica nanoparticles in rat experimental pneumonia. Biomed. Pharmacother. 2017, 92, 69-77. [CrossRef]

90. Heckman, K.L.; DeCoteau, W.; Estevez, A.; Reed, K.J.; Costanzo, W.; Sanford, D.; Leiter, J.C.; Clauss, J.; Knapp, K.; Gomez, C.; et al. Custom Cerium Oxide Nanoparticles Protect against a Free Radical Mediated Autoimmune Degenerative Disease in the Brain. ACS Nano 2013, 7, 10582-10596. [CrossRef]

91. Shen, C.; Liang, H.; Wang, C.; Liao, M.; Jan, T. Iron oxide nanoparticles suppressed T helper 1 cell-mediated immunity in a murine model of delayed-type hypersensitivity. Int J of nanomedicine 2012, 7, 2729-2737.

92. Shabanova, E.M.; Drozdov, A.S.; Fakhardo, A.F.; Dudanov, I.P.; Kovalchuk, M.S.; Vinogradov, V. $\mathrm{V}$ Thrombin@ $\mathrm{Fe}_{3} \mathrm{O}_{4}$ nanoparticles for use as a hemostatic agent in internal bleeding. Sci. Rep. 2018, 8, 233. [CrossRef] [PubMed]

93. MacParland, S.A.; Tsoi, K.M.; Ouyang, B.; Ma, X.-Z.; Manuel, J.; Fawaz, A.; Ostrowski, M.A.; Alman, B.A.; Zilman, A.; Chan, W.C.W.; et al. Phenotype Determines Nanoparticle Uptake by Human Macrophages from Liver and Blood. ACS Nano 2017, 11, 2428-2443. [CrossRef] [PubMed]

94. Sica, A.; Erreni, M.; Allavena, P.; Porta, C. Macrophage polarization in pathology. Cell. Mol. Life Sci. 2015, 72, 4111-4126. [CrossRef] [PubMed]

95. Tremble, L.; Moore, A.; Forde, P. Melanoma-conditioned medium promotes cytotoxic immune responses by murine bone marrow-derived monocytes despite their expression of "M2" markers. Cancer Immunol. Immunother. 2019, 68, 1455. [CrossRef] [PubMed]

96. Dukhinova, M.; Kopeikina, E.; Ponomarev, E.D. Usage of Multiparameter Flow Cytometry to Study Microglia and Macrophage Heterogeneity in the Central Nervous System during Neuroinflammation and Neurodegeneration. In Cellular Heterogeneity: Methods and Protocols; Barteneva, N.S., Vorobjev, I.A., Eds.; Springer: New York, NY, USA, 2018; pp. 167-177, ISBN 978-1-4939-7680-5. 
97. Luo, Y.H.; Chang, L.W.; Lin, P. Metal-Based Nanoparticles and the Immune System: Activation, Inflammation, and Potential Applications. Biomed. Res. Int. 2015, 2015, 143720. [CrossRef]

98. Feng, Y.; Mu, R.; Wang, Z.; Xing, P.; Zhang, J.; Dong, L.; Wang, C. A toll-like receptor agonist mimicking microbial signal to generate tumor-suppressive macrophages. Nat. Commun. 2019, 10, 2272. [CrossRef]

99. Han, Z.; Liu, S.; Lin, H.; Trivett, A.L.; Hannifin, S.; Yang, D.; Oppenheim, J.J. Inhibition of murine hepatoma tumor growth by cryptotanshinone involves TLR7-dependent activation of macrophages and induction of adaptive antitumor immune defenses. Cancer Immunol. Immunother. 2019, 68, 1073-1085. [CrossRef]

100. Yang, J.; Zhang, H.; Zhu, Z.; Gao, Y.; Xiang, B.; Wei, Q. The immunostimulatory effects and pro-apoptotic activity of rhCNB against Lewis lung cancer is mediated by Toll-like receptor 4. Cancer Med. 2019, 8, 4441-4453. [CrossRef]

101. Wolf-Grosse, S.; Mollnes, T.E.; Ali, S.; Stenvik, J.; Nilsen, A.M. Iron oxide nanoparticles enhance Toll-like receptor-induced cytokines in a particle size- and actin-dependent manner in human blood. Nanomedicine 2018, 13, 14. [CrossRef]

102. Chao, Y.; Karmali, P.P.; Simberg, D. Role of Carbohydrate Receptors in the Macrophage Uptake of Dextran-Coated Iron Oxide Nanoparticles. In Nano-Biotechnology for Biomedical and Diagnostic Research; Zahavy, E., Ordentlich, A., Yitzhaki, S., Shafferman, A., Eds.; Springer: Dordrecht, The Netherlands, 2012; pp. 115-123, ISBN 978-94-007-2555-3.

103. Jin, R.; Liu, L.; Zhu, W.; Li, D.; Yang, L.; Duan, J.; Cai, Z.; Nie, Y.; Zhang, Y.; Gong, Q.; et al. Iron oxide nanoparticles promote macrophage autophagy and inflammatory response through activation of toll-like Receptor-4 signaling. Biomaterials 2019, 203, 23-30. [CrossRef] [PubMed]

104. Potnis, P.A.; Dutta, D.K.; Wood, S.C. Toll-like receptor 4 signaling pathway mediates proinflammatory immune response to cobalt-alloy particles. Cell. Immunol. 2013, 282, 53-65. [CrossRef] [PubMed]

105. Zahra, D.; Ramia, S.; Mélanie, L.-L.; Sara, N.; Hilary, C.; David, M.; Bertrand, R.; Luc, F.; Olivier, J. Protein and lipid homeostasis altered in rat macrophages after exposure to metallic oxide nanoparticles. Cell Biol. Toxicol. 2019, 35, 1-18. [CrossRef] [PubMed]

106. Popp, L.; Tran, V.; Patel, R.; Segatori, L. Autophagic response to cellular exposure to titanium dioxide nanoparticles. Acta Biomater. 2018, 79, 354-363. [CrossRef] [PubMed]

107. Song, W.; Soo Lee, S.; Savini, M.; Popp, L.; Colvin, V.L.; Segatori, L. Ceria Nanoparticles Stabilized by Organic Surface Coatings Activate the Lysosome-Autophagy System and Enhance Autophagic Clearance. ACS Nano 2014, 8, 10328-10342. [CrossRef]

108. Noelia, A.; Quintana, J.A.; García-Silva, S.; Mazariegos, M.; González de la Aleja, A.; Nicolás-Ávila, J.A.; Walter, W.; Adrover, J.M.; Crainiciuc, G.; Kuchroo, V.K.; et al. Phagocytosis imprints heterogeneity in tissue-resident macrophages. J. Exp. Med. 2017, 214, 1281-1296.

109. Nicolás-Ávila, J.A.; Hidalgo, A.; Ballesteros, I. Specialized functions of resident macrophages in brain and heart. J. Leukoc. Biol. 2018, 104, 743-756. [CrossRef]

110. Espert, L.; Varbanov, M.; Robert-Hebmann, V.; Sagnier, S.; Robbins, I.; Sanchez, F.; Lafont, V.; Biard-Piechaczyk, M. Differential role of autophagy in CD4 T cells and macrophages during X4 and R5 HIV-1 infection. PLoS ONE 2009, 4, e5787. [CrossRef]

111. Poon, W.-L.; Alenius, H.; Ndika, J.; Fortino, V.; Kolhinen, V.; Meščeriakovas, A.; Wang, M.; Greco, D.; Lähde, A.; Jokiniemi, J.; et al. Nano-sized zinc oxide and silver, but not titanium dioxide, induce innate and adaptive immunity and antiviral response in differentiated THP-1 cells. Nanotoxicology 2017, 11, 936-951. [CrossRef]

112. Dhupal, M.; Oh, J.-M.; Tripathy, D.R.; Kim, S.-K.; Koh, S.B.; Park, K.-S. Immunotoxicity of titanium dioxide nanoparticles via simultaneous induction of apoptosis and multiple toll-like receptors signaling through ROS-dependent SAPK/JNK and p38 MAPK activation. Int. J. Nanomed. 2018, 13, 6735-6750. [CrossRef]

113. Feng, Q.; Liu, Y.; Huang, J.; Chen, K.; Huang, J.; Xiao, K. Uptake, distribution, clearance, and toxicity of iron oxide nanoparticles with different sizes and coatings. Sci. Rep. 2018, 8, 2082. [CrossRef] [PubMed]

114. Zhou, Y.; Que, K.-T.; Zhang, Z.; Yi, Z.J.; Zhao, P.X.; You, Y.; Gong, J.-P.; Liu, Z.-J. Iron overloaded polarizes macrophage to proinflammation phenotype through ROS/acetyl-p53 pathway. Cancer Med. 2018, 7, 4012-4022. [CrossRef] [PubMed]

115. Wang, D.; Zhao, L.; Ma, H.; Zhang, H.; Guo, L.-H. Quantitative Analysis of Reactive Oxygen Species Photogenerated on Metal Oxide Nanoparticles and Their Bacteria Toxicity: The Role of Superoxide Radicals. Environ. Sci. Technol. 2017, 51, 10137-10145. [CrossRef] [PubMed] 
116. Roy, R.; Singh, S.K.; Das, M.; Tripathi, A.; Dwivedi, P.D. Toll-like receptor 6 mediated inflammatory and functional responses of zinc oxide nanoparticles primed macrophages. Immunology 2014, 142, 453-464. [CrossRef]

117. Kim, S.Y.; Jeong, J.-M.; Kim, S.J.; Seo, W.; Kim, M.-H.; Choi, W.-M.; Yoo, W.; Lee, J.-H.; Shim, Y.-R.; Yi, H.-S.; et al. Pro-inflammatory hepatic macrophages generate ROS through NADPH oxidase 2 via endocytosis of monomeric TLR4-MD2 complex. Nat. Commun. 2017, 8, 2247. [CrossRef]

118. Yuan, Y.; Chen, Y.; Peng, T.; Li, L.; Zhu, W.; Liu, F.; Liu, S.; An, X.; Luo, R.; Cheng, J.; et al. Mitochondrial ROS-induced lysosomal dysfunction impairs autophagic flux and contributes to M1 macrophage polarization in a diabetic condition. Clin. Sci. 2019, 133, 1759-1777. [CrossRef]

119. Agarwal, H.; Nakara, A.; Shanmugam, V.K. Anti-inflammatory mechanism of various metal and metal oxide nanoparticles synthesized using plant extracts: A review. Biomed. Pharmacother. 2019, 109, 2561-2572. [CrossRef]

120. Chen, G.; Xu, Y. Biosynthesis of cerium oxide nanoparticles and their effect on lipopolysaccharide (LPS) induced sepsis mortality and associated hepatic dysfunction in male Sprague Dawley rats. Mater. Sci. Eng. C 2018, 83, 148-153. [CrossRef]

121. Wu, H.-Y.; Chung, M.-C.; Wang, C.-C.; Huang, C.-H.; Liang, H.-J.; Jan, T.-R. Iron oxide nanoparticles suppress the production of IL-1beta via the secretory lysosomal pathway in murine microglial cells. Part. Fibre Toxicol. 2013, 10, 46. [CrossRef]

122. Miao, X.; Leng, X.; Zhang, Q. The Current State of Nanoparticle-Induced Macrophage Polarization and Reprogramming Research. Int. J. Mol. Sci. 2017, 18, 336. [CrossRef]

123. Ndika, J.; Seemab, U.; Poon, W.-L.; Fortino, V.; El-Nezami, H.; Karisola, P.; Alenius, H. Silver, titanium dioxide, and zinc oxide nanoparticles trigger miRNA/isomiR expression changes in THP-1 cells that are proportional to their health hazard potential. Nanotoxicology 2019, 1-16. [CrossRef] [PubMed]

124. Tian, Y.; Yang, C.; Yao, Q.; Qian, L.; Liu, J.; Xie, X.; Ma, W.; Nie, X.; Lai, B.; Xiao, L.; et al. Procyanidin B2 Activates PPAR $\gamma$ to Induce M2 Polarization in Mouse Macrophages. Front. Immunol. 2019, 10, 1895. [CrossRef] [PubMed]

125. Bianchi, M.G.; Allegri, M.; Chiu, M.; Costa, A.L.; Blosi, M.; Ortelli, S.; Bussolati, O.; Bergamaschi, E. Lipopolysaccharide Adsorbed to the Bio-Corona of $\mathrm{TiO}_{2}$ Nanoparticles Powerfully Activates Selected Pro-inflammatory Transduction Pathways. Front. Immunol. 2017, 8, 866. [CrossRef] [PubMed]

126. Piaszyk-Borychowska, A.; Széles, L.; Csermely, A.; Chiang, H.-C.; Wesoły, J.; Lee, C.-K.; Nagy, L.; Bluyssen, H.A.R. Signal Integration of IFN-I and IFN-II with TLR4 Involves Sequential Recruitment of STAT1-Complexes and NFkB to Enhance Pro-inflammatory Transcription. Front. Immunol. 2019, 10, 1253. [CrossRef] [PubMed]

127. Lin, J.; Shi, S.; Zhang, J.; Zhang, Y.; Zhang, L.; Liu, Y.; Jin, P.; Wei, P.; Shi, R.; Zhou, W.; et al. Giant Cellular Vacuoles Induced by Rare Earth Oxide Nanoparticles are Abnormally Enlarged Endo/Lysosomes and Promote mTOR-Dependent TFEB Nucleus Translocation. Small 2016, 12, 5759-5768. [CrossRef] [PubMed]

128. Chen, M.; Liang, J.; Ji, H.; Yang, Z.; Altilia, S.; Hu, B.; Schronce, A.; McDermott, M.S.J.; Schools, G.P.; Lim, C.-U.; et al. CDK8/19 Mediator kinases potentiate induction of transcription by NFkB. Proc. Natl. Acad. Sci. USA 2017, 114, 10208-10213. [CrossRef]

129. Kim, T.; Cho, E.J.; Chae, Y.; Kim, M.; Oh, A.; Jin, J.; Lee, E.S.; Baik, H.; Haam, S.; Suh, J.S.; et al. Urchin-shaped manganese oxide nanoparticles as $\mathrm{pH}$-responsive activatable $T_{1}$ contrast agents for magnetic resonance imaging. Angew. Chem. Int. Ed. 2011, 50, 10589-10593. [CrossRef]

130. Gilad, A.A.; Walczak, P.; McMahon, M.T.; Hyon, B.N.; Jung, H.L.; An, K.; Hyeon, T.; Van Zijl, P.C.M.; Bulte, J.W.M. MR tracking of transplanted cells with "positive contrast" using manganese oxide nanoparticles. Magn. Reson. Med. 2008, 60, 1-7. [CrossRef]

131. Bridot, J.L.; Faure, A.C.; Laurent, S.; Rivière, C.; Billotey, C.; Hiba, B.; Janier, M.; Josserand, V.; Coll, J.L.; Vander Elst, L.; et al. Hybrid gadolinium oxide nanoparticles: Multimodal contrast agents for in vivo imaging. J. Am. Chem. Soc. 2007, 129, 5076-5084. [CrossRef]

132. Park, J.Y.; Choi, E.S.; Baek, M.J.; Lee, G.H.; Woo, S.; Chang, Y. Water-soluble Ultra Small paramagnetic or superparamagnetic metal oxide nanoparticles for molecular MR imaging. Eur. J. Inorg. Chem. 2009, 2009, 2477-2481. [CrossRef] 
133. Aaron, J.S.; Oh, J.; Larson, T.A.; Kumar, S.; Milner, T.E.; Sokolov, K.V. Increased optical contrast in imaging of epidermal growth factor receptor using magnetically actuated hybrid gold/iron oxide nanoparticles. Opt. Express 2006, 14, 12930-12943. [CrossRef] [PubMed]

134. Sharkey, J.; Starkey Lewis, P.J.; Barrow, M.; Alwahsh, S.M.; Noble, J.; Livingstone, E.; Lennen, R.J.; Jansen, M.A.; Carrion, J.G.; Liptrott, N.; et al. Functionalized superparamagnetic iron oxide nanoparticles provide highly efficient iron-labeling in macrophages for magnetic resonance-based detection in vivo. Cytotherapy 2017, 19, 555-569. [CrossRef] [PubMed]

135. Millward, J.M.; Ariza de Schellenberger, A.; Berndt, D.; Hanke-Vela, L.; Schellenberger, E.; Waiczies, S.; Taupitz, M.; Kobayashi, Y.; Wagner, S.; Infante-Duarte, C. Application of Europium-Doped Very Small Iron Oxide Nanoparticles to Visualize Neuroinflammation with MRI and Fluorescence Microscopy. Neuroscience 2019, 403, 136-144. [CrossRef] [PubMed]

136. Ikeda, H.; Ishii, A.; Sano, K.; Chihara, H.; Arai, D.; Abekura, Y.; Nishi, H.; Ono, M.; Saji, H.; Miyamoto, S. Activatable fluorescence imaging of macrophages in atherosclerotic plaques using iron oxide nanoparticles conjugated with indocyanine green. Atherosclerosis 2018, 275, 1-10. [CrossRef] [PubMed]

137. Yoon, S.H.; Lee, C.; Park, J.; Goo, J.M.; Park, J.-Y. In-vivo Visualization of Iron Oxide Enhancement in Focal Pulmonary Inflammatory Lesions Using a Three-Dimensional Radial Gradient-Echo-Based Ultrashort Echo Time Sequence: A Preliminary Study. Korean J. Radiol. 2018, 19, 153-157. [CrossRef] [PubMed]

138. Yin, X.; Li, Y.; Yang, C.; Weng, J.; Wang, J.; Zhou, J.; Feng, B. Alginate/chitosan multilayer films coated on IL-4-loaded $\mathrm{TiO}_{2}$ nanotubes for modulation of macrophage phenotype. Int. J. Biol. Macromol. 2019, 133, 503-513. [CrossRef]

139. Revia, R.A.; Stephen, Z.R.; Zhang, M. Theranostic Nanoparticles for RNA-Based Cancer Treatment. Acc. Chem. Res. 2019, 52, 1496-1506. [CrossRef]

140. Wang, J.; Lee, J.S.; Kim, D.; Zhu, L. Exploration of Zinc Oxide Nanoparticles as a Multitarget and Multifunctional Anticancer Nanomedicine. ACS Appl. Mater. Interfaces 2017, 9, 39971-39984. [CrossRef]

141. Richard, S.; Saric, A.; Boucher, M.; Slomianny, C.; Geffroy, F.; Mériaux, S.; Lalatonne, Y.; Petit, P.X.; Motte, L. Antioxidative Theranostic Iron Oxide Nanoparticles toward Brain Tumors Imaging and ROS Production. ACS Chem. Biol. 2016, 11, 2812-2819. [CrossRef]

142. Gan, J.; Liu, C.; Li, H.; Wang, S.; Wang, Z.; Kang, Z.; Huang, Z.; Zhang, J.; Wang, C.; Lv, D.; et al. Accelerated wound healing in diabetes by reprogramming the macrophages with particle-induced clustering of the mannose receptors. Biomaterials 2019, 219, 119340. [CrossRef]

143. Tarin, C.; Carril, M.; Martin-Ventura, J.L.; Markuerkiaga, I.; Padro, D.; Llamas-Granda, P.; Moreno, J.A.; García, I.; Genicio, N.; Plaza-Garcia, S.; et al. Targeted gold-coated iron oxide nanoparticles for CD163 detection in atherosclerosis by MRI. Sci. Rep. 2015, 5, 17135. [CrossRef] [PubMed]

144. Rubio-Navarro, A.; Carril, M.; Padro, D.; Guerrero-Hue, M.; Tarín, C.; Samaniego, R.; Cannata, P.; Cano, A.; Villalobos, J.M.A.; Sevillano, Á.M.; et al. CD163-Macrophages Are Involved in Rhabdomyolysis-Induced Kidney Injury and May Be Detected by MRI with Targeted Gold-Coated Iron Oxide Nanoparticles. Theranostics 2016, 6, 896-914. [CrossRef] [PubMed]

145. Jeong, J.; Kim, S.-H.; Lee, S.; Lee, D.-K.; Han, Y.; Jeon, S.; Cho, W.-S. Differential Contribution of Constituent Metal Ions to the Cytotoxic Effects of Fast-Dissolving Metal-Oxide Nanoparticles. Front. Pharmacol. 2018, 9, 15. [CrossRef] [PubMed]

146. Sharma, A.; Singh, V.; Gera, R.; Purohit, M.; Ghosh, D. Zinc Oxide Nanoparticle Induces Microglial Death by NADPH-Oxidase-Independent Reactive Oxygen Species as well as Energy Depletion. Mol. Neurobiol. 2017, 54, 6273. [CrossRef] [PubMed]

147. Hu, Q.; Zhao, F.; Fan, M.; He, C.; Yang, X.; Huang, Z.; Fu, Z. The influence of titanium dioxide nanoparticles on their cellular response to macrophage cells. Comp. Biochem. Physiol. Part C Toxicol. Pharmacol. 2019, 223, 42-52. [CrossRef] [PubMed]

148. Das, B.K.; Verma, S.K.; Das, T.; Panda, P.K.; Parashar, K.; Suar, M.; Parashar, S.K.S. Altered electrical properties with controlled copper doping in $\mathrm{ZnO}$ nanoparticles infers their cytotoxicity in macrophages by ROS induction and apoptosis. Chem. Biol. Interact. 2019, 297, 141-154. [CrossRef] [PubMed]

149. Yao, S.; Feng, X.; Lu, J.; Zheng, Y.; Wang, X.; Volinsky, A.A.; Wang, L.-N. Antibacterial activity and inflammation inhibition of $\mathrm{ZnO}$ nanoparticles embedded $\mathrm{TiO}_{2}$ nanotubes. Nanotechnology 2018, 29, 244003. [CrossRef] 
150. Li, X.; Huang, Q.; Liu, L.; Zhu, W.; Elkhooly, T.A.; Liu, Y.; Feng, Q.; Li, Q.; Zhou, S.; Liu, Y.; et al. Reduced inflammatory response by incorporating magnesium into porous $\mathrm{TiO}_{2}$ coating on titanium substrate. Colloids Surf. B Biointerfaces 2018, 171, 276-284. [CrossRef]

151. Bonan, R.F.; Mota, M.F.; da Costa Farias, R.M.; da Silva, S.D.; Bonan, P.R.F.; Diesel, L.; Menezes, R.R.; da Cruz Perez, D.E. In vitro antimicrobial and anticancer properties of $\mathrm{TiO}_{2}$ blow-spun nanofibers containing silver nanoparticles. Mater. Sci. Eng. C 2019, 104, 109876. [CrossRef]

(c)

(C) 2019 by the authors. Licensee MDPI, Basel, Switzerland. This article is an open access article distributed under the terms and conditions of the Creative Commons Attribution (CC BY) license (http://creativecommons.org/licenses/by/4.0/). 